\title{
READINESS OF STUDENTS OF A MEDICAL UNIVERSITY TO USE DISTANCE LEARNING TECHNOLOGIES
}

Milushkina OYu${ }^{1}$, Popov $\mathrm{V}^{2}$, Skoblina $\mathrm{NA}^{1} \otimes$, Markelova SV${ }^{1}$, Fedotov $\mathrm{DM}^{3}$, levleva OV${ }^{1}$

${ }_{1}^{1}$ Pirogov Russian National Research Medical University

${ }^{2}$ Burdenko Voronezh State Medical University

${ }^{3}$ Northern State Medical University

This study aimed to assess the readiness of students of a medical university to use distance learning technologies. For the purpose, specialists of the Department of Hygiene of Pediatric Faculty at the Pirogov Russian National Research Medical University developed online questionnaires. The study involved 508 people studying at the Pirogov Russian National Research Medical University and the Northern State Medical University. The data obtained were processed with Statistica 13.0. Forty-five percent of the respondents stated their electronic device use skill was "high", while $53 \%$ considered it to be "basic". Seventeen percent of the students noted that they were stressed out. Following factors could have caused the stress reactions: $22.0 \%$ of the respondents reported worsened interpersonal relationships with their fellow students, $23.4 \%$ saw their relations with professors deteriorating, $13.0 \%$ noted their health has gone worse. The most common (91.9\% of cases) learning quality control method applied relied on online tests. In $41.5 \%$ of cases, the tests were followed by an interview with the professor. This pattern of learning quality control was appreciated by $74.4 \%$ of the respondents. The score given by the respondents to the teaching staff for their performance was $3.9 \pm 0.04$ points out of 5 ; the total number of negative opinions given was $30.0 \%$. The study revealed medical university students to be highly ready to use distance learning technologies. Careful attention should be paid to identifying individuals who have difficulties with adapting to the use of distance learning technologies, as well as to work aimed at development of students' health preservation competencies that are useful in both in-person and distance learning scenarios.

Keywords: students, electronic devices, distance learning

Author contribution: Milushkina OYu, Popov VI, Skoblina NA — scientific guidance, writing an article; Markelova SV, Fedotov DM, levleva OV — collection of material, statistical processing, literature analysis

Compliance with ethical standards: This study was approved by the LEK Pirogov Russian National Research Medical University (Protocol № 203 dated 20.12.2020). Voluntary informed consent was obtained for each participant. The online survey for the adult population was conducted on a voluntary basis using an online service. The conducted research does not endanger the participants and complies with the requirements of biomedical ethics.

Correspondence should be addressed: Natalia A. Skoblina

Ostrovityanova st. 1, Moscow, 117997; skoblina_dom@mail.ru

Received: 18.03.2021 Accepted: 26.03.2021 Published online: 29.03.2021

DOI: $10.24075 /$ rbh.2021.001

\section{ГОТОВНОСТЬ ОБУЧАЮЩИХСЯ МЕДИЦИНСКОГО ВУЗА К ИСПОЛЬЗОВАНИЮ ДИСТАНЦИОННЫХ ОБРАЗОВАТЕЛЬНЫХ ТЕХНОЛОГИЙ}

О. Ю. Милушкина' , В. И. Попов², Н. А. Скоблина' $₫$, С. В. Маркелова', Д. М. Федотов³, О. В. Иевлева

${ }^{1}$ Российский национальный исследовательский медицинский университет имени Н. И. Пирогова, Москва, Россия

2 Воронежский государственный медицинский университет им. Н. Н. Бурденко, г. Воронеж, Россия

${ }^{3}$ Северный государственный медицинский университет, г. Архангельск, Россия

Целью исследования являлась оценка готовности обучающихся медицинского вуза к использованию дистанционных образовательных технологий. Для этого сотрудниками кафедры гигиены педиатрического факультета РНИМУ им. Н.И. Пирогова были разработаны опросники, распространяемые через онлайн-сервис. В исследовании приняли участие 508 человек, обучающихся в РНИМУ им. Н.И. Пирогова и ФГБОУ ВО СГМУ. Статистическая обработка проводилась с использованием Statistica 13.0. 45\% опрошенных оценили свой навык использования электронных устройств как «высокий» и 53\% как «базовый». 17,0\% обучающихся отметили, что испытывали состояние стресса. Возможными причинами стрессовых реакций могли стать следующие факты: у 22\% опрошенных ухудшились межличностные отношения между сокурсниками, у 23,4\% ухудшились отношения с преподавателями, 13,0\% отметили ухудшение состояния здоровья. В качестве формы контроля качества усвоения знаний, наибольшее (в 91,9\% случаев) распространение получил он-лайн тестовый контроль, который в 41,5\% случаев был дополнен устным собеседованием с преподавателем. 74,4\% опрошенных оказались довольны формой контроля знаний. Работу профессорско-преподавательского состава респонденты оценили на 3,9 \pm 0,04 из 5 возможных, общее число негативных оценок составило 30,0\%. Показана высокая готовность обучающихся медицинского вуза к использованию дистанционных образовательных технологий. Пристальное внимание должно быть уделено выявлению лиц, имеющих трудности с адаптацией к использованию дистанционных образовательных технологий и работе по формированию у обучающихся компетенций связанных со здоровьесбережением, которые они могут реализовывать как при очном, так и при дистанционном обучении

Ключевые слова: обучающиеся, электронные устройства, дистанционное обучение

Вклад авторов: Милушкина О.Ю., Попов В.И., Скоблина Н.А. - научное руководство, написание статьи; Маркелова С.В., Федотов Д.М., Иевлева О.В. сбор материала, статистическая обработка, анализ литературы.

Соблюдение этических стандартов: Данное исследование было одобрено ЛЭК РНИМУ им. Н.И. Пирогова (Протокол № 203 от 20.12.2020). Добровольное информированное согласие было получено для каждого участника. Проведение онлайн-опроса для взрослого населения проводилось на добровольной основе с использованием онлайн-сервиса. Проведенное исследование не подвергает опасности участников и соответствует требованиям биомедицинской этики.

$\triangle$ Для корреспонденции: Скоблина Наталья Александровна

ул. Островитянова, д. 1, г. Москва, 117997, skoblina_dom@mail.ru

Статья получена: 18.03.2021 Статья принята к печати: 26.03.2021 Опубликована онлайн: 29.03.2021

DOI: 10.24075/rbh.2021.001 
The widespread integration of distance learning technologies into educational processes at various levels, including medical personnel training, is regulated by the Federal Law 273-FZ of December 29, 2012 "On Education in the Russian Federation" and Order of the Ministry of Education and Science of the Russian Federation of August 23, 2017 "On approval of e-learning, distance learning technologies application Procedure followed by educational institutions in the context of their primary activities" [1-2].

Distance learning offers a number of indisputable advantages, like the possibility of choosing the time and pace of learning, which is especially relevant to asynchronous curricula models. However, there are also some risks associated therewith. The most prominent of them are risks of students physical and mental health deterioration resulting from improper organization of the educational process. Therefore, it is the task for higher education institutions to develop health preservation competencies of students and encourage them to lead a healthy lifestyle, including in the context of distance learning [3].

The epidemiological situation of 2020 calls for thorough consideration of the accumulated experience of distance learning in medical universities, as well as appraisal of the readiness of all educational process participants to implement distance learning practices.

This study aimed to assess the readiness of students of a medical university to use distance learning technologies and learn their opinion of this form of education provision.

\section{MATERIALS AND METHODS}

Specialists of the Department of Hygiene of Pediatric Faculty at the Pirogov Russian National Research Medical University developed online (Google Forms) questionnaires enabling assessment of readiness of the medical university students to practice distance learning [4]. The specialists are certified in General Hygiene, Hygienic Education, Hygiene of Children and Adolescents, Epidemiology. The questionnaires contained questions phrased to reveal the respondents' level of awareness of the risk factors associated with distance learning, specifics of organization of educational process when studying in absentia, and learn their opinions of this form of education provision.

The study involved 508 students (years 1 through 6) studying at the Pirogov Russian National Research Medical University and the Northern State Medical University. Eighty percent of the respondents are female. The inclusion criteria were status of a student, availability of a signed informed consent and a correctly completed questionnaire. The exclusion criteria were lack of the said status (not being a student), lack of a signed informed consent and a correctly completed questionnaire.

This study was approved by the Ethics Committee of Pirogov Russian National Research Medical University (Minutes \#203 December 20, 2020). Each participant signed a voluntary informed consent form. The conducted study does not endanger the participants and complies with the biomedical ethics requirements.

Statistical processing of the data was enabled by Statistica 13.0 (StatSoft Inc.; USA).

\section{RESULTS}

As part of assessment of readiness of medical university students to use distance learning technologies there were developed three blocks of questions that allowed evaluating:
1) their technical readiness (availability of electronic devices, level of proficiency with information and communication technologies);

2) their psychological readiness (presence of stressful situations, rational self-organization of educational process, motivation for learning, communication with colleagues, professors, etc.);

3) their methodological readiness (respondents' satisfaction with the education provision and learning quality control methods applied at the universities).

The first block (technical readiness) revealed that $45 \%$ of the respondents believe their electronic device use skill is "high", while 53\% consider it to be "basic". Only 2\% of the study participants rated their electronic device use skill as "insufficient".

In 2020, distance learning was practiced for a long period of time (several months), so $85.5 \%$ of the respondents considered stationary electronic devices to be the most convenient appliances therefor, with $83.1 \%$ owning a desktop computer or a laptop and $70.5 \%$ using them to participate in distance learning activities. The rest used mobile electronic devices (smartphones, tablets) for the purpose.

As for the other distance learning prerequisites: $90.9 \%$ of respondents had access to the internet, $83.1 \%$ had their own stationary electronic device, $75.6 \%$ had a dedicated workplace, and $63.2 \%$ had a separate room. Such a high proportion of people with a separate room may be associated with the fact that many students left dormitories for the places of their permanent residence when COVID-19 restrictions were imposed.

Thus, the readiness of future doctors for distance learning in terms of electronic device use skills and the prerequisites therefor can be characterized as quite high.

As for the psychological readiness for distance learning, it was established that $83 \%$ of the respondents were able to quickly adapt to the new conditions. Only $4 \%$ of the respondents failed to adapt to the discussed education practices, which corresponds to the self-assessment of electronic device use skill expressed by study participants.

Subjective scores given by the respondents when assessing the level of stress during the distance learning period averaged at $2.5 \pm 0.06$ points out of 5 . However, $17.0 \%$ of the students noted that they experienced stress. Following factors could have caused the stress reactions: $22.0 \%$ of the respondents reported worsened interpersonal relationships with their fellow students, $23.4 \%$ saw their relations with professors deteriorating, $13.0 \%$ noted their health has gone worse.

The analysis of respondents' opinions of their daily regimen during the distance learning period revealed deterioration thereof in $37.0 \%$ of cases. Sixty percent of the respondents noted that they had more free time. Half of the students stated their preference for passive rest (reading, watching movies, playing computer games), which did not contribute to health preservation. Restriction imposed in most regions of the country that prevented active recreation could have played their part in this situation.

As for the methodological aspects of the distance learning process, the analysis shows that $79.8 \%$ of the respondents used Zoom and $46.9 \%$ relied on Skype. Thus, in the context of synchronous curricula, the possibility of live communication with the professors was preserved. Online lectures made up $72.2 \%$ of distance learning hours, $61.2 \%$ of cases evolved into full-fledged classes and a third took form of online discussions and consultations. In $64.0 \%$ of cases, duration of classes did not increase. Overall, $70.0 \%$ of the respondents were satisfied with presentation of the educational material. 
During the distance learning period, most $(71.1 \%)$ future doctors actively used online resources when preparing for classes (downloaded books, referred to materials published to the university website). As a result, according to $64.2 \%$ of the respondents, their homework and preparing time has increased. It should be emphasized separately that the students identified a number of subjects that, in their opinion, cannot be studied remotely: anatomy, histology, operative surgery, topographic anatomy, and a number of clinical disciplines.

The most common ( $91.9 \%$ of cases) learning quality control method applied relied on online tests. In $41.5 \%$ of cases, the tests were followed by an interview with the professor. This pattern of learning quality control was appreciated by $74.4 \%$ of the respondents. The score given by the respondents to the teaching staff for their performance was $3.9 \pm 0.04$ points out of 5 ; the total number of negative opinions given was $30.2 \%$.

Thus, it should be noted that most respondents expressed their positive opinion of using distance learning elements in the educational process. The negative scores given by $13.2 \%$ of the respondents may come from the difficulties with adaptation to the new conditions, stress and the ways the professors have organized the learning process in. In general, from the point of view of effectiveness, distance learning scored $3.3 \pm 0.05$ points out of 5 . Half of the respondents noted that in the conditions of distance learning, it is necessary to teach hygienic practices that pertain to the development of electronic device safe use skills and health preservation.

\section{DISCUSSION}

Development of the education system, transition to the new educational standards is associated with the continuously growing requirements for level of qualifications of specialists that have received higher education. This goal is achievable provided the volume and speed of mastering the information studied increase, same as the volume of work done by the students on their own, and if distance learning technologies are introduced to the educational process. Distance learning relies on stationary and mobile electronic devices, the use of which can have a negative effect on health of young people [5-8]. For medical educational establishments, the tasks of developing health preservation skills of future doctors and encouraging them to lead a healthy lifestyle acquire special importance [9].

Foreign experience also signals of possible problems associated with introduction of distance learning. In the context of medical education, students faced the duality of traditional and active teaching methods, which made them concerned about various (numerous) aspects of life [10, 11].

Same as us, the researchers abroad have shown that the majority of respondents perceive online lectures positively, but this does not apply to small group exercises, including autopsy sessions. Less than half of the respondents exhibited anxiety symptoms [12-14].

One of the most significant factors contributing to the success of distance learning is previous online learning experience $(p<0.01)$. This experience correlated positively with the students' assessment of and satisfaction with their current online education activities [15].

In the context of distance learning, it is necessary to improve the educational process, use active learning methods, such as web quests, business games [16, 17]. These technologies enable quick adaptation to online learning, with additional benefits being flexibility, mobility, agility, stability, cultural security and justice [18]. The variety of existing online platforms fit for distance learning purposes requires appropriate training of professors and teachers and improvement of their skills [19,20].

\section{CONCLUSIONS}

The study shows that medical university students are highly ready to use distance learning technologies. The key to increasing the effectiveness of distance education is the improvement of forms of teaching, introduction of their active varieties and improvement of skills of teachers and professors. Careful attention should be paid to identifying individuals who have difficulties with adapting to the use of distance learning technologies, as well as to work aimed at encouraging students to lead healthy lifestyles and development of their health preservation competencies that are useful in both in-person and distance learning scenarios.

\section{References}

1. Federal'nyy zakon № 237-FZ «Ob obrazovanii v Rossiyskoy Federatsii» [Elektronnyy resurs, data obrashcheniya 18.03.2021].

2. Prikaz Ministerstva obrazovaniya i nauki RF ot 23 avgusta 2017 g. Russian. № 816 «Ob utverzhdenii Poryadka primeneniya organizatsiyami, osushchestvlyayushchimi obrazovatel'nuyu deyatel'nost', elektronnogo obucheniya, distantsionnykh obrazovatel'nykh tekhnologiy pri realizatsii obrazovatel'nykh programm» [Elektronnyy resurs, data obrashcheniya 18.03.2021].

3. Milushkina OYu, Skoblina NA, Markelova SV, Tatarinchik AA, Bokareva NA, Fedotov DM. Otsenka riskov zdorov'yu shkol'nikov i studentov pri vozdeystvii obuchayushchikh i dosugovykh informatsionno-kommunikatsionnykh tekhnologiy. Analiz riska zdorov'yu. 2019; (3): 135-143. Russian.

4. Pivovarov YuP, Skoblina NA, Milushkina OYu, Markelova SV, Fedotov DM, Okol'nikov FB. i dr. Ispol'zovanie internetoprosov $v$ otsenke osvedomlennosti ob osnovakh zdorovogo obraza zhizni. Sovremennye problemy zdravookhraneniya i meditsinskoy statistiki. 2020; (2): 398-413. Russian.

5. Marchuk NYu. Psikhologo-pedagogicheskie osobennosti distantsionnogo obucheniya. Pedagogicheskoe obrazovanie $v$ Rossii. 2013; (4): 75-85. Russian.

6. Kuznetsova OV. Distantsionnoe obuchenie: za i protiv.

Mezhdunarodnyy zhurnal prikladnykh i fundamental'nykh issledovaniy. 2015; 8 (2): 362-364. Russian.

7. Klimenskikh MV, Korepina NA, Sheka AS, Vindeker OS. Osobennosti vospriyatiya distantsionnogo obucheniya studentami i prepodavatelyami vuza. Sovremennye problemy nauki i obrazovaniya. 2018; (1): URL: http://science-education.ru/ru/ article/view?id=27421 (data obrashcheniya: 18.03.2021).

8. Popov MV, Libina II, Melikhova EP. Otsenka vliyaniya gadzhetov na psikhoemotsional'noe sostoyanie studentov. Molodezhnyy innovatsionnyy vestnik. 2019; 8 (2): 676-678. Russian.

9. Krylov VM, Krylova AV, Ponomareva TA. Osobennosti zdorov'esberegayushchego povedeniya studentov. Kazanskiy sotsial'no-gumanitarnyy vestnik. 2019; 6 (41): 28-32. Russian.

10. Marsilli LRB, Smecellato FB, Junior OCS. Medical education in COVID-19 pandemic: Medical students' point of view. Medicina. 2020; 53 (4): 490-4.

11. Sindiani AM, Obeidat N, Alshdaifat E, Elsalem L, Alwani MM, Rawashdeh $\mathrm{H}$. et al. Distance education during the COVID-19 utbreak: A cross-sectional study among medical students in north of jordan. Ann Med Surgrnet. 2020; 59: 186-194.

12. Cuschieri S, Calleja Agius J. Spotlight on the shift to remote anatomical teaching during covid-19 pandemic: Perspectives and 
experiences from the university of malta. Anat Sci Educ. 2020; 13 (6): 671-9.

13. Rizun M, Strzelecki A. Students' acceptance of the covid-19 impact on shifting higher education to distance learning in poland. Int J Environ Res Public Health. 2020; 17 (18): 1-19.

14. Armstrong-Mensah E, Ramsey-White K, Yankey B, Self-Brown S. COVID-19 and distance learning: Effects on georgia state university school of public health students. Front Public Health. 2020; 8.

15. Wang C, Xie A, Wang W, Wu H. Association between medical students' prior experiences and perceptions of formal online education developed in response to COVID-19: A cross-sectional study in china. BMJ Open. 2020; 10 (10).

16. П16. Pastyuk OV. Icpol'zovanie interaktivny"kh form obucheniya bakalavrov pri izuchenii distsipliny «Bezopasnost' zhiznedeyatel'nosti». Kazanskiy pedagogicheskiy zhurnal. 2018; 2 (127): 79- 85. Russian.
17. Badiyedpeymaie Jahromi Z. Integrated method of teaching in Web Quest activity and its impact on undergraduate students' cognition and learning behaviors: a future trend in medical education. Glob J Health Sci. 2015; 7 (4): 249-259.

18. Currie G, Hewis J, Nelson T, Chandlerb A, Nabasenjab C, Spuura K. et al. COVID-19 impact on undergraduate teaching: Medical radiation science teaching team experience. J Med Imaging Radiat Sci. 2020; 51 (4): 518-27.

19. Haroon Z, Azad AA, Sharif M, Aslam A, Arshad K, Rafiq S. COVID-19 era: Challenges and solutions in dental education. J Coll Phys Surg Pak. 2020; 30 (2): 129-31.

20. Chertoff JD, Zarzour JG, Morgan DE, Lewis PJ, Canon CL, Harvey JA. The early influence and effects of the coronavirus disease 2019 (COVID-19) pandemic on resident education and adaptations. J Am Coll Radiol. 2020; 17 (10): 1322-1328.

\section{Литература}

1. Федеральный закон № 237-ФЗ «Об образовании в Российской Федерации» [Электронный ресурс, дата обращения 18.03.2021]

2. Приказ Министерства образования и науки РФ от 23 августа 2017 г. № 816 «Об утверждении Порядка применения организациями, осуществляющими образовательную деятельность, электронного обучения, дистанционных образовательных технологий при реализации образовательных программ» [Электронный ресурс, дата обращения 18.03.2021].

3. Милушкина О.Ю., Скоблина Н.А., Маркелова С.В., Татаринчик А.А., Бокарева Н.А., Федотов Д.М. Оценка рисков здоровью школьников и студентов при воздействии обучающих и досуговых информационно-коммуникационных технологий. Анализ риска здоровью. 2019; (3): 135-143.

4. Пивоваров Ю.П., Скоблина Н.А., Милушкина О.Ю., Маркелова С.В., Федотов Д.М., Окольников Ф.Б. и др. Использование интернет - опросов в оценке осведомленности об основах здорового образа жизни. Современные проблемы здравоохранения и медицинской статистики. 2020; (2): 398-413.

5. Марчук Н.Ю. Психолого-педагогические особенности дистанционного обучения. Педагогическое образование в России. 2013; (4): 75-85.

6. Кузнецова О.В. Дистанционное обучение: за и против. Международный журнал прикладных и фундаментальных исследований. 2015; 8 (2): 362-364.

7. Клименских М.В., Корепина Н.А., Шека А.С., Виндекер О.С. Особенности восприятия дистанционного обучения студентами и преподавателями вуза. Современные проблемы науки и образования. 2018; (1): URL: http://science-education. ru/ru/article/view?id=27421 (дата обращения: 18.03.2021).

8. Попов М.В., Либина И.И., Мелихова Е.П. Оценка влияния гаджетов на психоэмоциональное состояние студентов. Молодежный инновационный вестник. 2019; 8 (2): 676-678.

9. Крылов В.М., Крылова А.В., Пономарева Т.А. Особенности здоровьесберегающего поведения студентов. Казанский социально-гуманитарный вестник. 2019; 6 (41): 28-32.

10. Marsilli L.R.B., Smecellato F.B., Junior O.C.S. Medical education in COVID-19 pandemic: Medical students' point of view. Medicina. 2020; 53 (4): 490-4.

11. Sindiani A.M., Obeidat N., Alshdaifat E., Elsalem L., Alwani M.M., Rawashdeh $\mathrm{H}$. et al. Distance education during the COVID-19 utbreak: A cross-sectional study among medical students in north of jordan. Ann Med Surgrnet. 2020; 59: 186-194.

12. Cuschieri S., Calleja Agius J. Spotlight on the shift to remote anatomical teaching during covid-19 pandemic: Perspectives and experiences from the university of malta. Anat Sci Educ. 2020; 13 (6): 671-9.

13. Rizun M., Strzelecki A. Students' acceptance of the covid-19 impact on shifting higher education to distance learning in poland. Int J Environ Res Public Health. 2020; 17 (18): 1-19.

14. Armstrong-Mensah E., Ramsey-White K., Yankey B., Self-Brown S. COVID-19 and distance learning: Effects on georgia state university school of public health students. Front Public Health. 2020; 8.

15. Wang C., Xie A., Wang W., Wu H. Association between medical students' prior experiences and perceptions of formal online education developed in response to COVID-19: A cross-sectional study in china. BMJ Open. 2020; 10 (10).

16. Пастюк О.В. Использование интерактивныъх форм обучения бакалавров при изучении дисциплины «Безопасность жизнедеятельности». Казанский педагогический журнал. 2018; 2 (127): 79-85.

17. Badiyedpeymaie Jahromi Z. Integrated method of teaching in Web Quest activity and its impact on undergraduate students' cognition and learning behaviors: a future trend in medical education. Glob J Health Sci. 2015; 7 (4): 249-259.

18. Currie G., Hewis J., Nelson T., Chandlerb A., Nabasenjab C., Spuura K. et al. COVID-19 impact on undergraduate teaching: Medical radiation science teaching team experience. J Med Imaging Radiat Sci. 2020; 51 (4): 518-27.

19. Haroon Z., Azad A.A., Sharif M., Aslam A., Arshad K., Rafiq S. COVID-19 era: Challenges and solutions in dental education. J Coll Phys Surg Pak. 2020; 30 (2): 129-31.

20. Chertoff J.D., Zarzour J.G., Morgan D.E, Lewis P.J., Canon C.L., Harvey J.A. The early influence and effects of the coronavirus disease 2019 (COVID-19) pandemic on resident education and adaptations. J Am Coll Radiol. 2020; 17 (10): 1322-1328. 